\title{
Effect of sugar industrial wastes on sweet potato (Ipomoea batatas L.) yield and roots quality
}

\author{
Mahmoud G. A. H., Mahmoud E. A., Younes N. A.* \\ Department of Horticulture, Faculty of Agriculture, Al-Azhar University, Assiut, Egypt
}

\begin{abstract}
Two field experiments were conducted at a private farm in Malawi city, El-Minya, Egypt during two successive seasons of 2018 and 2019 respectively, to study the effect of organic, inorganic and its combination fertilizers on sweet potato yield and quality in a sandy clay loam soil, Treatments were (T1) $100 \%$ of inorganic fertilizer (NPK at mineral form), (T2) 100\% organic fertilizer (sugarcane bagasse ash plus sugarcane vinasse), (T3) $75 \%$ organic fertilizer $+25 \%$ inorganic, (T4) $50 \%$ organic fertilizer $+50 \%$ inorganic, (T5) $25 \%$ organic fertilizer $+75 \%$ inorganic. A random complete block design (RCBD) with three replications was used. The data showed a high response to the full dose of organic fertilization treatments (5 ton /feddan of sugarcane bagasse ash plus $80 \mathrm{~L}$ /feddan of sugarcane vinasse (feddan $=4200 \mathrm{~m}^{2}=$ 0.420 hectares $=1.037$ acres)) at all vegetative growth and tuberous roots yield and quality. Meanwhile, the lowest values of sweet potato characters were obtained with full dose of inorganic fertilizers (NPK).
\end{abstract}

Keywords: sugarcane bagasse ash, sugarcane vinasse, sweet potato, Ipomoea batatas.

*Corresponding author: Younes N. A., 


\section{Introduction}

Sweet potato (Ipomoea batatas L.) is a dicotyledonous plant belonging to the Convolvulaceae family (Woolfe, 1992). The plant is an herbaceous perennial vine with alternate heart-shaped leaves. Sweet potato ranked as the seventh economic crop after wheat, rice, maize, potato, barley, and cassava (FAO 2009). Sweet potato is one of the important root crops in Egypt and many other countries in the world especially the Eastern and Southern parts of the African continent (Tumwegamire et al., 2004). Sweet potato requires low inputs and less management and is an important food security crop grown in many of the poorest regions of the world mainly by women for food and as a source of food and family cash income (Woolfe, 1992). Sweet potato is valued for its roots which can be boiled, fried, baked, or roasted for humans or boiled and fed to livestock as a source of energy (Boru, 2017). Orange-fleshed varieties are rich in beta-carotene, while purple-fleshed varieties are high in anthocyanins, two important antioxidants thought to prevent chronic heart diseases and cancer (Drapal et al., 2019; Teow et al., 2007). Significant amounts of essential minerals are found in sweet potato, including manganese, copper, iron, and potassium, which are the most prevalent mineral (Huang, 1982). The total cultivated area in the year of 2017 reached about 18590 feddan with a total production of about 287244 tons and a mean of 9-17 tons /feddan (feddan = $4200 \mathrm{~m}^{2}=0.420$ hectares $=1.037$ acres). According to Department of Agricultural Economic Statistics, Egyptian Ministry of
Agriculture and Land Reclamation, sweet potato cultivated areas were in El-Behera, Kafr-Elsheikh, and Damietta governorates (Anonymous, 2013). Sweet potato may be adapted to grow on poor soils; as such most farmers do not apply fertilizer to their crops, resulting in poor yield. Small-holder farmers apply little or no fertilizer, often citing high cost or nonavailability of inorganic fertilizers as reasons for not applying recommended dosage. Though inorganic fertilizers have been the conventional method of soil mineral input in sweet potato production, these fertilizers may pose danger to the environment especially if inappropriately applied. According to Buresh et al. (1997) and Palm et al. (1997), it has generally been accepted that both inorganic and organic inputs are needed to increase crop production. The concept of 'integrated nutrient management' utilizing all available organic and inorganic resources has become a dominant paradigm for improved or increased yields in smallholder agriculture system of subSaharan Africa (SSA) to ensure both efficient and economic use of scarce nutrient resources (Smailing et al., 1997; Vanluawe et al., 2001). Sugar industry waste is one of the alternative organic sources to improve soil quality and plant growth. Bagasse ash and vinasse is a byproduct of distillery industries produced mostly from raw materials of sugarcane. Bagasse is the fibrous material remaining after removing the sucrose, water, and other extraneous material impurities (e.g. sediment) from the delivered sugarcane. Bagasse on a dry weight basis is composed of $40-50 \%$ cellulose, $30-35 \%$ hemicellulose, 20-30\% lignin, and a small 
percentage of other materials (Amin, 2011; Cardona et al., 2010; Drummond and Drummond, 1996; Martin et al., 2007; Pandey et al., 2000; Sales and Lima, 2010). On the other hand, sugarcane vinasse is produced from juice and often with molasses, has more concentration of carbon, potassium, phosphate, sulphate, calcium, iron, sodium and other micronutrient than former (Gopal and Kammen, 2009) and has lot of organic compounds such as glycerol, lactic acid and acetic acid (Decloux et al., 2002). Therefore, the use of organic materials to supplement inorganic fertilizer use, as an integrated management strategy, is of paramount importance to reducing the cost of soil mineral input, maximizing yields and sustaining sweet potato as well as other food crops production. Accordingly, the present study was carried out to achieve the following goals: Determination of the suitable rates of vinasse and bagasse ash as an organic fertilizer under different concentrations to obtain high yield with good root quality. Minimizing the added inorganic fertilization rates and, thereby, lowering the total production cost. Trying to find the right combination of organic and inorganic fertilizers to obtain high yield with good root quality.

\section{Materials and methods}

\subsection{Experimental site}

The experiments were performed on the sweet potato (Ipomoea batatas L.) at an a private farm in, Malawi, City, El-Minya, Egypt located at $28.0871^{\circ} \mathrm{N}, 30.7618^{\circ} \mathrm{E}$ during two successive summer seasons of 2018 and 2019 respectively, to study the effect of organic, inorganic and its combination fertilizers on sweet potato yield and quality in a sandy clay loam soil as presented in Table (1).

Table (1): The physical and chemical properties of the samples taken from experimental soil during the two cultivated seasons.

\begin{tabular}{|l|l|l|l|}
\hline Characteristic & Value & Characteristic & Value \\
\hline O.M. (\%) & 0.0062 & $\mathrm{Mg}^{+2}(\%)$ & 0.036 \\
\hline $\mathrm{CaCO}_{3}(\%)$ & 1.62 & $\mathrm{Na}^{+}(\%)$ & 6.5 \\
\hline Sand $(\%)$ & 55.2 & $\mathrm{~K}^{+}(\%)$ & 0.035 \\
\hline Silt $(\%)$ & 20.8 & Available (ppm) & --- \\
\hline Clay $(\%)$ & 24 & $\mathrm{NH}_{4}(\%)$ & 48.0 \\
\hline Texture class & Sand clay loam & $\mathrm{N}(\%)$ & 0.032 \\
\hline pH & 7.4 & $\mathrm{P}(\%)$ & 0.0054 \\
\hline EC $(\mathrm{d} / \mathrm{m})$ & 2.4 & $\mathrm{Zn}(\%)$ & 2.5 \\
\hline $\mathrm{Cl}$ & 0.355 & $\mathrm{Ca}^{+2}(\%)$ & 0.03 \\
\hline
\end{tabular}

\subsection{Experimental materials}

Sugarcane bagasse ash and vinasse were obtained from Qus Sugarcane Company, Qus, City, Qena, Egypt and was used as an organic fertilizer. In addition, mineral forms of NPK was used as an inorganic fertilizer. Chemical analysis of bagasse ash and vinasse are presented in Tables (2) and (3). 
Table (2): Sugarcane vinasse chemical composition.

\begin{tabular}{|l|c|}
\hline Parameter & Vinasse \\
\hline $\mathrm{pH}$ & 4.1 \\
\hline $\mathrm{EC}(\mathrm{dS} / \mathrm{m})$ (electrical conductivity) & $22 \mathrm{dS} / \mathrm{m}$ \\
\hline $\mathrm{BOD}(\mathrm{mg} / \mathrm{L})$ (biochemical oxygen demand) & 50000 \\
\hline $\mathrm{COD}(\mathrm{mg} / \mathrm{L})$ (chemical oxygen demand) & 96000 \\
\hline $\mathrm{N}(\%)$ & 0.13 \\
\hline $\mathrm{P}(\%)$ & 0.00 \\
\hline $\mathrm{K}(\%)$ & 0.79 \\
\hline $\mathrm{Ca}(\mathrm{ppm})$ & 0.0 \\
\hline $\mathrm{Na}(\mathrm{ppm})$ & 0.0 \\
\hline $\mathrm{Fe}(\mathrm{ppm})$ & 12.07 \\
\hline $\mathrm{Mn}(\mathrm{ppm})$ & 0.42 \\
\hline $\mathrm{Zn}(\mathrm{ppm})$ & 0.7 \\
\hline $\mathrm{Cu}(\mathrm{ppm})$ & 0.27 \\
\hline
\end{tabular}

Mabroka and Abis sweet potato varieties which used in this thesis were obtained from Arab El-Awamer Station, Agriculture Research Center. Vines cuttings of $25 \mathrm{~cm}$ length from apical sections and other actively growing sections were planted in rows, $0.75 \mathrm{~m}$ apart, and at spacing of $0.50 \mathrm{~m}$ within rows under a drip irrigation system.

Table (3): Sugarcane bagasse ash chemical composition.

\begin{tabular}{|l|l|}
\hline Mineral & Percentage (\%) \\
\hline $\mathrm{SiO}_{2}$ & 73 \\
\hline $\mathrm{Al}_{2} \mathrm{O}_{3}$ & 6.7 \\
\hline $\mathrm{Fe}_{2} \mathrm{O}_{3}$ & 6.3 \\
\hline $\mathrm{CaO}$ & 2.8 \\
\hline $\mathrm{MgO}$ & 3.2 \\
\hline $\mathrm{P}_{2} \mathrm{O}_{5}$ & 4.0 \\
\hline $\mathrm{Na}_{2} \mathrm{O}$ & 1.1 \\
\hline $\mathrm{K}_{2} \mathrm{O}$ & 2.4 \\
\hline
\end{tabular}

\subsection{Experimental design and treatments}

A random complete block design (RCBD) with three replications was used. Vines cuttings of $25 \mathrm{~cm}$ length from apical sections and other actively growing sections were planted on ridges at a spacing of $1 \mathrm{~m}$ between ridges and
$0.3 \mathrm{~m}$ within rows, under a drip irrigation system. Two-thirds of each vines (with 4 to 6 nodes) was buried into the soil (about 15 to $20 \mathrm{~cm}$ deep) leaving onethird above the soil. Each plot size consisted of three ridges with each ridge being $3.5 \mathrm{~m}$ long. Treatments were $\left(\mathrm{T}_{1}\right)$ $100 \%$ of inorganic fertilizer (NPK at mineral form), $\left(\mathrm{T}_{2}\right) \quad 100 \%$ organic fertilizer (bagasse ash plus vinasse), $\left(\mathrm{T}_{3}\right)$ $75 \%$ inorganic fertilizer $+25 \%$ organic, ( $\left.\mathrm{T}_{4}\right) \quad 50 \%$ organic fertilizer $+50 \%$ inorganic, $\left(\mathrm{T}_{5}\right) 25 \%$ organic fertilizer + $75 \%$ inorganic (Table 4). The mineral form of the inorganic fertilizer used in this study was mono calcium superphosphate $\left(15.5 \% \mathrm{P}_{2} \mathrm{O}_{5}\right)$, potassium sulphate $\left(\begin{array}{lll}48 \% & \left.\mathrm{~K}_{2} \mathrm{O}\right)\end{array}\right)$ and ammonium nitrate $(33.5 \% \mathrm{~N})$.

\subsection{Agricultural operations}

At soil preparation time, the full dose of mono calcium superphosphate $\left(\mathrm{P}_{2} \mathrm{O}_{5}\right)$ and bagasse ash with their different levels were added. Meanwhile, ammonium nitrate $(33.5 \% \mathrm{~N})$, potassium sulphate $\left(48 \% \quad \mathrm{~K}_{2} \mathrm{O}\right)$ and vinasse fertilizer with their different levels was added to the soil throughout the drip irrigation system. All the agricultural practices used for commercial sweet potato production were carried out in this experiment (Hassan, 1991).

\subsection{Data collected}

Final harvesting was done when the leaves had turned brown to determine the 
influence of the treatments on plant height $(\mathrm{cm})$, tuberous root number per plant, average weight of a single tuber root $(\mathrm{g})$, average diameter of tuberous root $(\mathrm{cm})$, tuberous root yield per plant $(\mathrm{kg})$ and tuberous root yield per feddan (ton) as well as total carbohydrate percentage $(\%)$.

Table (4): Total amount of inorganic and organic fertilizers.

\begin{tabular}{|l|l|l|l|}
\hline \multirow{2}{*}{$\begin{array}{l}\text { Treatment } \\
\text { code }\end{array}$} & \multirow{2}{*}{$\begin{array}{l}\text { Treatments } \\
(\%)\end{array}$} & \multicolumn{1}{|c|}{ Inorganic } & \multicolumn{1}{c|}{ Organic } \\
\cline { 3 - 4 } & NPK $(\mathrm{Kg} / \mathrm{feddan})$ & Bagasse $(\mathrm{Kg} /$ feddan $)+$ Vinasse (L/feddan) \\
\hline $\mathrm{T}_{1}$ & 100 & $150-400-160$ & $0.0+0.0$ \\
\hline $\mathrm{T}_{2}$ & 100 & $0.0-0.00 .0$ & 5 ton/feddan $+80 \mathrm{~L} / \mathrm{feddan}$ \\
\hline $\mathrm{T}_{3}$ & $75+25$ & $112.5-300-120$ & 1.25 ton/feddan $+20 \mathrm{~L} / \mathrm{feddan}$ \\
\hline $\mathrm{T}_{4}$ & $50+50$ & $75-200-80$ & 2.5 ton/feddan $+40 \mathrm{~L} / \mathrm{feddan}$ \\
\hline $\mathrm{T}_{5}$ & $25+75$ & $37.5-100-40$ & 3.75 ton/feddan $+60 \mathrm{~L} / \mathrm{feddan}$ \\
\hline
\end{tabular}

Sample preparation for chemical content analyses were performed on sweet potato tubers at 3 days after harvesting. The sample was comprised of 7 tubers taken randomly from each treatment, which were then washed, peeled, and cut to a size of $23 \mathrm{~mm}$ using a grated knife. The tubers were then heated in an oven at $60^{\circ} \mathrm{C}$ for 5 hours. After the sliced tubers were removed from the oven, they were milled and sieved with a size 80 mesh sieve. The samples used for chemical testing were measured on a dry weight base and stored in plastic bags at $4{ }^{\circ} \mathrm{C}$ (Dako et al., 2016). The chemical analysis of carbohydrate levels and crude protein percentage (\%) were process according to Bach et al. (2018).

\subsection{Statistical analysis}

The analysis of variance of the data was carried out on the mean values of the tested treatments according to the procedures described by Gomez and Gomez (1984). The least significant differences (LSD) at 5\% levels was used for testing the significance of the differences among the mean values of the tested treatments for each character.

\section{Results}

Response of sweet potato cultivars to organic and inorganic fertilizer treatments are presented in the following chapter. Data of sweet potato height in $\mathrm{cm}$ are presented in Table (5). Results revealed that, significantly effect of fertilizer treatments and cultivars on sweet potato plant height. Mabroka cv. recorded the shortest plants (132.90 and $130.68 \mathrm{~cm}$ ) than the Abis cv. (166.17 and $166.20 \mathrm{~cm})$ in the first and second season, respectively. Full dos of organic treatment $\left(\mathrm{T}_{2}\right)$ and the combined with fifty percent of organic and inorganic fertilizer treatment $\left(\mathrm{T}_{4}\right)$ scored the highest values of sweet potato length $\mathrm{cm}$ in the tow cultivated seasons. Significant interactions were detected between sweet 
potato cultivars and the fertilizer in both seasons, respectively. Meanwhile, treatments. Sweet potato cv. at $\mathrm{T}_{2}$ and $\mathrm{T}_{4} \quad 25 \%$ organic $+75 \%$ inorganic fertilizer fertilizer treatments recorded the longest treatment $\left(\mathrm{T}_{5}\right)$ scored the shortest plants plants than the other fertilizer treatments in both seasons, respectively.

Table (5): Effect of organic and inorganic fertilizer on plant height of sweet potato $(\mathrm{cm})$.

\begin{tabular}{|l|l|l|l|l|l|l|}
\hline \multirow{2}{*}{ Treatment code } & \multicolumn{3}{|c|}{2018} & \multicolumn{3}{c|}{2019} \\
\cline { 2 - 8 } & Mabroka & Abis & Means (a) & Mabroka & Abis & Means (a) \\
\hline $\mathrm{T}_{1}$ & 132.17 & 165.67 & 148.92 & 130.13 & 166.00 & 147.89 \\
\hline $\mathrm{T}_{2}$ & 139.80 & 172.00 & 155.90 & 135.93 & 169.33 & 152.63 \\
\hline $\mathrm{T}_{3}$ & 135.18 & 166.68 & 150.93 & 131.23 & 161.00 & 146.12 \\
\hline $\mathrm{T}_{4}$ & 136.67 & 170.17 & 153.42 & 135.13 & 170.68 & 152.90 \\
\hline $\mathrm{T}_{5}$ & 130.68 & 156.33 & 143.51 & 127.00 & 164.00 & 145.67 \\
\hline Means (b) & 132.90 & 166.17 & --- & 130.68 & 166.20 & --- \\
\hline LSD & $\mathrm{a}=2.18$ & $\mathrm{~b}=3.44 \quad \mathrm{ab}=4.86$ & $\mathrm{a}=3.58 \quad \mathrm{~b}=5.67 \mathrm{ab}=8.02$ \\
\hline
\end{tabular}

Significant affect was obtained from the data which, presented in Table (6) for the number of tuberous roots affected by cultivars, fertilizer treatments and the combined effect. In both cultivated seasons of 2018 and 2019, Mabroka cv. scored the maximum tuberous roots number. Maximum values of tuberous roots number were detected by add 5 ton /feddan of bagasse ash plus $80 \mathrm{~L} /$ feddan of vinasse (treatment $\mathrm{T}_{2}$ ) followed by $50 \%$ of NPK plus $50 \%$ of bagasse ash and vinasse (treatment $\mathrm{T}_{4}$ ) in both seasons. The interaction effect showed that, highly effect of fertilizer treatment on tuberous roots number. $\mathrm{T}_{2}$ and $\mathrm{T}_{4}$ scored the maximum number of sweet potato tuberous roots at the cultivars in both seasons of 2018 and 2019, respectively.

Table (6): Effect of organic and inorganic fertilizer on number of tuberous root per plant of sweet potato.

\begin{tabular}{|l|l|l|l|l|l|l|}
\hline \multirow{2}{*}{ Treatment code } & \multicolumn{3}{|c|}{2018} & \multicolumn{3}{c|}{2019} \\
\cline { 2 - 8 } & Mabroka & Abis & Means (a) & Mabroka & Abis & Means (a) \\
\hline $\mathrm{T}_{1}$ & 4.70 & 4.00 & 4.35 & 4.40 & 4.20 & 4.30 \\
\hline $\mathrm{T}_{2}$ & 5.80 & 4.90 & 5.35 & 5.40 & 4.60 & 5.00 \\
\hline $\mathrm{T}_{3}$ & 4.90 & 4.70 & 4.80 & 4.85 & 4.46 & 4.74 \\
\hline $\mathrm{T}_{4}$ & 5.20 & 4.80 & 5.00 & 5.20 & 4.55 & 4.87 \\
\hline $\mathrm{T}_{5}$ & 4.80 & 4.60 & 4.70 & 4.76 & 4.33 & 4.54 \\
\hline Means (b) & 5.08 & 4.60 & --- & 4.92 & 4.42 & --- \\
\hline LSD & \multicolumn{9}{|l|}{$\mathrm{a}=0.24 \mathrm{~b}=0.37 \mathrm{ab}=0.53$} & $\mathrm{a}=0.24 \quad \mathrm{~b}=0.39 \quad \mathrm{ab}=0.55$ \\
\hline
\end{tabular}

On the other hand, full dos of inorganic fertilizer $\left(\mathrm{T}_{1}\right)$ scored the lowest values of tuberous roots number in both seasons. Data presented in Table (7) showed that, 
significantly effect of sweet potato cultivars, organic and inorganic fertilizer treatments and the interaction effect on tuberous root diameter in both cultivated seasons of 2018 and 2019. Abis cv. recorded the lowest tuberous root diameter than the Mabroka cv. in both seasons, respectively. Also, $\mathrm{T}_{1}$ fertilizer scored the lowest diameter of sweet potato tuberous root in the two successive seasons of 2018 and 2019, respectively. While, $\mathrm{T}_{2}$ fertilizer treatment followed by $\mathrm{T}_{4}$ obtained the maximum diameter of sweet potato tuberous root in the two successive seasons of 2017 and 2018, respectively. The combined effect of sweet potato cultivars and fertilizer treatments shoed that, $T_{2}$ and $T_{1}$ at the two cultivars of sweet potato recorded the highest and lowest values of tuberous roots diameter, respectively, in both seasons.

Table (7): Effect of organic and inorganic fertilizer on mean of tuberous root diameter $(\mathrm{cm})$ of sweet potato.

\begin{tabular}{|l|l|l|l|l|l|l|}
\hline \multirow{2}{*}{ Treatment code } & \multicolumn{3}{|c|}{2018} & \multicolumn{3}{c|}{2019} \\
\cline { 2 - 8 } & Mabroka & Abis & Means (a) & Mabroka & Abis & Means (a) \\
\hline $\mathrm{T}_{1}$ & 6.87 & 6.10 & 6.48 & 6.10 & 6.22 & 6.16 \\
\hline $\mathrm{T}_{2}$ & 7.21 & 6.85 & 7.03 & 7.00 & 6.93 & 6.96 \\
\hline $\mathrm{T}_{3}$ & 6.80 & 6.66 & 6.73 & 6.75 & 6.71 & 6.73 \\
\hline $\mathrm{T}_{4}$ & 7.00 & 6.96 & 6.84 & 6.91 & 6.88 & 6.89 \\
\hline $\mathrm{T}_{5}$ & 6.80 & 6.22 & 6.51 & 6.00 & 6.65 & 6.32 \\
\hline Means (b) & 6.93 & 6.55 & --- & 6.55 & 6.67 & --- \\
\hline LSD & $\mathrm{a}=1.51 \quad \mathrm{~b}=2.40 \quad \mathrm{ab}=3.39$ & $\mathrm{a}=1.35 \quad \mathrm{~b}=2.14 \quad \mathrm{ab}=3.03$ \\
\hline
\end{tabular}

There was significant difference between the weight of tuberous root in the study. Application of full dos of bagasse ash and vinasse $\left(\mathrm{T}_{2}\right)$ produced higher mean value of 355.45 and $387.74 \mathrm{~g}$ in first and second seasons, respectively. Also, Abis $\mathrm{cv}$. gave the highest tuberous root value 331.53 and $365.07 \mathrm{~g}$ in the first and second seasons of 2018 and 2019 respectively. While, Mabroka cv. scored the lowest value of tuberous root as weight in $\mathrm{g}$. The combined effect of fertilizer treatment and sweet potato cultivars showed positively values of pure amount of bagasse ash and vinasse $\left(T_{2}\right)$ on weight of tuberous roots than the other fertilizer treatments in both seasons respectively. On the other hand, pure dose of NPK fertilizer $\left(T_{2}\right)$ scored the lowest means of tuberous roots weight in both seasons (Table 8). Data presented in Tables (9) exhibit the effect of five proportions of inorganic and organic fertilizer treatments on tuberous roots yield of sweet potato per plants $(\mathrm{kg})$. Application of $100 \%$ organic fertilizer (T2) resulted in the highest yield weight (kg) per plant in both seasons. There was no significant difference between the sweet potato $\mathrm{cv}$. tuberous roots yield per plant in the study. The combined treatment of $50 \%$ inorganic plus $50 \%$ 
organic fertilizer produced the highest total yield as weight $\mathrm{kg}$ per plant in the both seasons. In contrast, the application of $100 \%$ inorganic fertilizer source (T1) was always inferior compared to other four proportion treatments regarding to tuberous roots yield during the two growing seasons.

Table (8): Effect of organic and inorganic fertilizer on average weight of single sweet potato tuber root $(\mathrm{g})$.

\begin{tabular}{|l|l|l|l|l|l|l|}
\hline \multirow{2}{*}{$\begin{array}{l}\text { Treatment } \\
\text { code }\end{array}$} & \multicolumn{3}{|c|}{2018} & \multicolumn{3}{c|}{2019} \\
\cline { 2 - 7 } & Mabroka & Abis & Means (a) & Mabroka & Abis & Means (a) \\
\hline $\mathrm{T}_{1}$ & 260.50 & 320.33 & 290.42 & 250.70 & 342.67 & 296.68 \\
\hline $\mathrm{T}_{2}$ & 370.57 & 340.33 & 355.45 & 380.30 & 395.17 & 387.74 \\
\hline $\mathrm{T}_{3}$ & 336.00 & 335.76 & 335.83 & 335.533 & 360.50 & 348.017 \\
\hline $\mathrm{T}_{4}$ & 351.17 & 338.33 & 344.75 & 350.800 & 377.00 & 363.9 \\
\hline $\mathrm{T}_{5}$ & 266.66 & 323.33 & 294.99 & 241.900 & 350.00 & 295.95 \\
\hline Means (b) & 316.98 & 331.53 & --- & 311.85 & 365.07 & --- \\
\hline LSD & $\mathrm{a}=8.75$ & $\mathrm{~b}=13.80 \quad \mathrm{ab}=19.51$ & $\mathrm{a}=10.19$ & $\mathrm{~b}=16.11 \mathrm{ab}=22.78$ \\
\hline
\end{tabular}

Table (9): Effect of organic and inorganic fertilizer on tuberous root yield per plant of sweet potato $(\mathrm{kg})$.

\begin{tabular}{|l|l|l|l|l|l|l|}
\hline \multirow{2}{*}{ Treatment code } & \multicolumn{3}{|c|}{2018} & \multicolumn{3}{c|}{2019} \\
\cline { 2 - 8 } & Mabroka & Abis & Means (a) & Mabroka & Abis & Means (a) \\
\hline $\mathrm{T}_{1}$ & 1.22 & 1.18 & 1.25 & 1.44 & 1.40 & 1.42 \\
\hline $\mathrm{T}_{2}$ & 1.95 & 1.87 & 1.91 & 1.56 & 1.77 & 1.67 \\
\hline $\mathrm{T}_{3}$ & 1.56 & 1.51 & 1.53 & 1.54 & 1.52 & 1.53 \\
\hline $\mathrm{T}_{4}$ & 1.82 & 1.63 & 1.73 & 1.76 & 1.54 & 1.65 \\
\hline $\mathrm{T}_{5}$ & 1.34 & 1.36 & 1.35 & 1.46 & 1.45 & 1.45 \\
\hline Means (b) & 1.60 & 1.45 & --- & 1.55 & 1.53 & --- \\
\hline LSD & $\mathrm{a}=0.10 \mathrm{~b}=\mathrm{ns}$ ab $=0.22$ & $\mathrm{a}=0.08 \quad \mathrm{~b}=\mathrm{ns} \quad \mathrm{ab}=0.17$ \\
\hline
\end{tabular}

There was significant difference between the fertilizer applied with the respect to tuberous roots yield per feddan of sweet potato. Full levels of organic fertilizer $\left(\mathrm{T}_{2}\right)$ produced the highest means value of yields as ton per feddan (30.12 and 30.58 ton /feddan) in the first and second seasons, respectively, which was followed by fifty percent of organic and inorganic fertilizer (T4) and the last mean value of tuberous yield (26.53 and 25.79 ton /feddan) from the pure dose of NPK fertilizer treatment in the first and second seasons, respectively (Table 10). There was no significant difference between the sweet potato $\mathrm{cv}$. tuberous roots yield per feddan in the study. Concerning the interaction effects between different proportion of chemical and organic sources and different sweet potato cv., the highest values of tuberous roots yield per feddan were obtained from bagasse ash and vinasse at $100 \%$ levels $\left(\mathrm{T}_{2}\right)$ combined with mabroka cv. followed by Abis cv. at same fertilizer treatment. In the same context Mabroka and Abis cv. 
at the full dose of inorganic fertilizer roots yield as ton per feddan in both treatment $\left(T_{1}\right)$ scored the lowest tuberous seasons of 2018 and 2019.

Table (10): Effect of organic and inorganic fertilizer on tuberous root yield per feddan of sweet potato (ton /feddan).

\begin{tabular}{|l|l|l|l|l|l|l|}
\hline \multirow{2}{*}{ Treatment code } & \multicolumn{3}{|c|}{2018} & \multicolumn{3}{c|}{2019} \\
\cline { 2 - 8 } & Mabroka & Abis & Means (a) & Mabroka & Abis & Means (a) \\
\hline $\mathrm{T}_{1}$ & 26.01 & 27.06 & 26.53 & 25.27 & 26.30 & 25.79 \\
\hline $\mathrm{T}_{2}$ & 30.34 & 29.90 & 30.12 & 31.22 & 29.95 & 30.58 \\
\hline $\mathrm{T}_{3}$ & 28.07 & 28.90 & 28.48 & 29.08 & 29.17 & 29.85 \\
\hline $\mathrm{T}_{4}$ & 28.90 & 29.00 & 28.95 & 29.80 & 29.90 & 29.85 \\
\hline $\mathrm{T}_{5}$ & 27.88 & 25.36 & 26.62 & 27.46 & 26.60 & 27.03 \\
\hline Means (b) & 28.24 & 28.04 & --- & 28.57 & 28.38 & --- \\
\hline LSD & $\mathrm{a}=0.42$ & $\mathrm{~b}=\mathrm{ns} a b=2.78$ & $\mathrm{a}=1.19$ & $\mathrm{~b}=\mathrm{ns} \quad \mathrm{ab}=2.66$ \\
\hline
\end{tabular}

The highest carbohydrate percentage in the tuberous roots of sweet potato was from organic fertilizer treated $\left(\mathrm{T}_{2}\right)$ and the least from the $25 \%$ inorganic plus $75 \%$ organic fertilizer treated $\left(\mathrm{T}_{5}\right)$. There was no significant difference between the sweet potato $\mathrm{cv}$. carbohydrate percent in the study (Table 11). Regarding the interaction effects between different sweet potato cultivars and different fertilizer application treatments, Mabroka cultivar which fertilized with full dose of bagasse ash and vinasse $\left(\mathrm{T}_{2}\right)$ resulted in the highest carbohydrate percentage, while Abis cv. which fertilized with $25 \%$ inorganic and $75 \%$ organic fertilizer $\left(\mathrm{T}_{5}\right)$ resulted in the lowest carbohydrate percentage.

Table (11): Effect of organic and inorganic fertilizer on carbohydrate and crude protein $(\%)$ of sweet potato.

\begin{tabular}{|l|l|l|l|l|l|l|}
\hline \multirow{2}{*}{ Treatment code } & \multicolumn{3}{|c|}{2018} & \multicolumn{3}{c|}{2019} \\
\cline { 2 - 8 } & Mabroka & Abis & Means (a) & Mabroka & Abis & Means (a) \\
\hline $\mathrm{T}_{1}$ & 32.33 & 32.01 & 32.17 & 3.20 & 3.27 & 3.24 \\
\hline $\mathrm{T}_{2}$ & 34.30 & 34.02 & 34.16 & 5.25 & 5.32 & 5.24 \\
\hline $\mathrm{T}_{3}$ & 31.13 & 31.05 & 31.09 & 3.17 & 3.13 & 3.15 \\
\hline $\mathrm{T}_{4}$ & 31.69 & 31.52 & 31.60 & 5.18 & 5.11 & 5.15 \\
\hline $\mathrm{T}_{5}$ & 30.56 & 30.46 & 30.51 & 4.21 & 4.15 & 4.18 \\
\hline Means (b) & 32.00 & 31.81 & --- & 4.20 & 4.19 & --- \\
\hline LSD & $\mathrm{a}=0.63 \quad \mathrm{~b}=\mathrm{ns} \quad \mathrm{ab}=1.02$ & $\mathrm{a}=0.65 \quad \mathrm{~b}=\mathrm{ns} \quad \mathrm{ab}=1.13$ \\
\hline
\end{tabular}

In crude protein production, the highest percentage was realized from organic fertilizer treated $\left(\mathrm{T}_{2}\right)$, followed by $50 \%$ organic plus $50 \%$ inorganic fertilizer treated $\left(\mathrm{T}_{2}\right)$, while the lowest percentage were recorded at $25 \%$ inorganic plus
$75 \%$ organic fertilizer treated $\left(\mathrm{T}_{5}\right)$. There was no significant difference between the sweet potato $\mathrm{cv}$. carbohydrate percent in the study (Table 11). Regarding the interaction effects between different sweet potato cultivars and different 
fertilizer application treatments, Abis cultivar which fertilized with full dose of bagasse ash and vinasse $\left(\mathrm{T}_{2}\right)$ resulted in the highest amount of crude protein percentage, while Abis cultivar which fertilized with $75 \%$ inorganic and $25 \%$ organic fertilizer $\left(T_{3}\right)$ resulted in the lowest amount of crude protein percentage.

\section{Discussion}

The present study aimed to reduce chemical fertilizers for sweet potato plants without reducing tuberous roots yield and also to improve tuberous roots quality through partial replacement of inorganic NPK with organic sources i.e. sugarcane bagasse ash and vinasse. Organic and inorganic fertilization treatments showed that, the highest values of growth characters, yield and tuberous roots quality were related to the application of $100 \%$ organic sources (bagasse ash and vinasse). Conversely, the lowest productivity was related to the application of $100 \%$ inorganic materials. On the other hand, the overlap between organic and inorganic fertilizers led to varying responses in all vegetative, yield and quality characters. Therefore, fertilization mode is ought to play an important role in sweet potato productivity. Whereas, sweet potato productivity is strongly affected by the different doses and sources of fertilizers. The highest growth and tuberous roots yield were related to the sufficient availability of NPK and other essential nutrients. Under this condition, plants developed the best growth indices so they could produce the highest yield. Although inorganic fertilizer when applied to crop usually has a quickreleased formula making nutrient rapidly available to plants, but because of the high cost and its long time adverse effect on soil chemical properties, organic fertilizer are recommended for use, organic fertilizer are environmentally friendly and it supply both macro and micro nutrients to the soil (Negassa et al., 2001; Tirol-padre et al., 2007) and also improve the physio-chemical properties of the soil. Calculated data of sweet potato characters under our studies pointed to the important role of organic fertilizer in form of sugarcane bagasse ash and vinasse for improving sweet potato traits, this results support the work of Webber et al. (2017) reported that, increasing the sugarcane bagasse ash percentage significantly influenced total exchange capacity, $\mathrm{pH}$, organic matter, estimated nitrogen release, and all other nutrients measured, except for sodium. At the same trend, Mwita et al. (2019) reported that, application of different levels of sugarcane bagasse positively influenced most of the yield parameters of Chinese cabbage (Brassica rapa subsp. pekinensis). Crop improved in response to its favorable effects on the soil characteristics. Utilization of sugarcane bagasse as organic fertilizer can save chemical fertilizers along with minimizing environmental pollution. By comparing the levels of sugarcane 
bagasse application they reported that, $10 \%$ was suggested to be the standard dose due to best yield parameters such as the root and shoot length of plant, root and shoot dry weight of plant, number of leaves and relative water content of Chinese cabbage (Brassica rapa pekinensis) crop in the soil amended with SCB. Also, In Greece, wheat production was increased by vinasse application, confirming the beneficial effects of the residue in agriculture. In Spain (Madejon et al., 2001), yields of beets and maize were compared after treatments with an organic compound based on vinasse or a mineral fertilizer. Crop production was similar in both treatments indicating that the utilization of vinasse is a viable alternative for mineral fertilizers. Rajagopal et al. (2014) reported that, rate of vinasse application in agriculture has added significant amount of nutrients, improved the soil quality of degraded land and increased of crop yields. In Mauritius, vinasse application of $100 \mathrm{~m} 3$ ha-1 for 10 years to sugarcane crops produces additionally cane yield of 80 to 90 tonnes that is equivalent to one more crop season (Soobadar and KeeKwong, 2012). The vinasse application increased significantly $\mathrm{N}, \mathrm{P}, \mathrm{K}, \mathrm{S}$ and Ca uptake as well as yield of sugarcane, wheat, pigeon pea and maize yield over the countries (Komdorfer and Anderson, 1993). Vegetable crops are sensitive to vinasse and irrigation by $33 \%$ dilution increased the fruit size and weight (Chidankumar $e t$ $a l ., 2009)$. The lowest values of growth characters, yield and tuberous roots quality were related to the application of $100 \%$ inorganic fertilizer source. This might be due to that available minerals in inorganic source was not sufficient for optimum sweet potato growth or it may be due to its loss by washing in sandy soil. This is line with the work of Errebhi et al. (1998) that potato is highly responsive to $\mathrm{N}$-fertilization and that $\mathrm{N}$ is usually the most limiting essential nutrient for potatoes growth and development. Although urea application effect was not different significantly from the poultry manure, poultry manure is preferred to urea in the study because of its ability to improve soil structure through the increased activities of microorganism in the soil. It is therefore concluded that poultry manure application wherever is available is the best for the production of sweet potato. The influence of fertilization to achieve a high yield and generally good quality of vegetable crops is well known. Good sweet potato yield is the result of integrated effects of many factors that influence plant growth during different growth stages. This is due to the fact that plants received much available NPK enhanced their vegetative growth and they could be reflected as more productivity for tuberous roots yield. The best proportion of NPK source depending on the available $\mathrm{NO}_{3}-\mathrm{N}, \mathrm{P}_{2} \mathrm{O}_{5}$ and $\mathrm{K}_{2} \mathrm{O}$ in organic source and in cultivated soli.

\section{Conclusion}

It may be concluded on the basis of 
present investigation that, organic fertilizer treatment which included sugarcane bagasse ash and vinasse with 5 ton and 80 liters per feddan respectively were more positively effects on vegetative growth characters and tuberous roots yield and quality of sweet potato crops than, the inorganic fertilizer treatment (NPK) or the different mixing ratios of them. on the other side, there is no significant differences between sweet potato cultivars under study in tuberous roots yield and quality.

\section{References}

Amin, N. (2011), "Use of bagasse ash in concrete and its impact on the strength and chloride resistivity", Journal of Materials in Civil Engineering, Vol. 23 No. 5, pp. 717-720.

Anonymous (2013), Country Programming Framework (CPF) Government of Egypt 2012-2017, Department of Agricultural Economic Statistics, The Ministry of Agriculture and Land Reclamation, Egypt and The Food and Agriculture Organization of the United Nations.

Bach, F., Helm, C. V. H., De Lima, E. A., Bellettini, M. B. and Haminiuk, C. W. I. (2018), "Influence of cultivation methods on the chemical and nutritional characteristics of Lentinula edodes", Emirates Journal of Food and Agriculture, Vol. 30 No. 12, pp. 1006-1013.
Boru, M., W/Tsadik, K. and Tana, T. (2017), " Effects of application of farmyard manure and inorganic phosphorus on tuberous root yield and yield related traits of sweet potato [Ipomoea batatas (L.) Lam] at Assosa, Western Ethiopia", Advances in Crop Science and Technology, Vol. 5 No. 4, Article No. 1000302.

Buresh, I. J., Sanchez, P. A. and Calhoun, F. (1997), Replenishing soil fertility in Africa, SSSA Special Publication 51, SSSA and ASA, Madison, Wisconsin, USA.

Cardona, C. A., Quintero, J. A., and Paz, I. C. (2010), "Production of bioethanol from sugarcane bagasse: Status and perspectives", Bioresource Technology, Vol. 101 No. 13, pp. 4754-4766.

Chidankumar, C. S., Chandraju, S. and Nagendraswamy, N. (2009), "Impact of distillery spent wash irrigation on the yields of top vegetables (Creepers)", World Applied Sciences Journal, Vol. 6 No. 9, pp. 1270 1273.

Dako, E., Retta, N. and Desse, G. (2016), "Comparison of three sweet potato (Ipomoea batatas (L.) Lam) varieties on nutritional and antinutritional factors", Global Journal of Science Frontier Research (D), Vol. 16 No. 4, pp. 63-72.

Decloux, M., Bories, A., Lewandowski, R., Fargues, C., Mersad, A., Lameloise, M., Bonnet, F., 
Dherbecourt, B. and Nieto, L. (2002), "Interest of electrodialysis to reduce potassium level in vinassePreliminary experiments", Desalination, Vol. 146, pp. 393398.

Drapal, M., Rossel, G. and Heider, B. (2019), "Metabolic diversity in sweet potato (Ipomoea batatas Lam.) leaves and storage roots", Horticulture Research, Vol. 6, Article No. 2.

Drummond, A. R. F. and Drummond, I. W. (1996), "Pyrolysis of sugar cane bagasse in a wire-mesh reactor", Ind. Eng. Chem. Res., Vol. 35 No. 4, pp. 1263-1268.

Errebhi, M., Rosen, C. J., Gupta, S. C. and Birong, D. E. (1998), "Potato yield response and nitrate leaching as influence by nitrogen management", Agronomy Journal, Vol. 90 Vol. 1, pp. 10-15.

FAO (2009), Agricultural Data FAOSTAT, Food and Agriculture Organization of the United Nations, Rome, Italy.

Gomez, K. A. and Gomez, A. A. (1984), Statistical Procedures for Agricultural Research, $2^{\text {nd }}$ ed., John Wiley \& Sons Inc., New York, USA.

Gopal, A., Kammen, D. (2009), "Molasses for ethanol: the economic and environmental impacts of a new pathway for the lifecycle greenhouse gas analysis of sugarcane ethanol",
Environmental Research Letters, Vol. 4, pp. 1-5.

Hassan, A. A. (1991), Production of Vegetable Crops, $1^{\text {st }}$ ed., Arab House for Publishing and Distribution, Cairo, Egypt (in Arabic).

Huang, P. C. (1982), Nutritive value of sweet potato, Proceedings of the First International Symposium on Sweet Potato, Asian Vegetable Research and Development Center, Taiwan.

Komdorfer, G. H. and Anderson, D. L. (1993), Use and impact of sugaralcohol residues vinasse and filter on sugarcane production in brazil, Proceedings of Inter-American Seminor 122, Miami, USA, pp. 164 170.

Madejon, E., Lopez, R., Jose, M. M. and Cabrera, F. (2001), Agricultural use of three (sugar-beet) vinasse composts: effect on crops and chemical properties of a Cambisol soil in the Guadalquivir river valley (SW Spain), Agriculture, Ecosystems \& Environment, Vol. 84, pp. 55-65.

Martin, C., Klinke, H. B. and Thomsen, A. B. (2007), "Wet oxidation as a pretreatment method for enhancing the enzymatic convertibility of sugarcane bagasse", Enzyme and Microbial Technology, Vol. 40, 426-432.

Mwita, S. C., Banyikwa, A. and 
Maheswara, R. V. (2019), "Soil amendments with sugarcane bagasse and its effect on soil humic acid contents and chinese cabbage growth components", Agricultural Research \& Technology, Vol. 21 No. 3, Article No. 556166.

Negassa, W., Negisho, K., Friesen, D. K., Ransom, J. and Yadessa, A. (2001), Determination of optimum farmyard manure and NP fertilizers for maize on farmers field, Seventh Eastern and Southern Africa Regional Maize Conference, Nairobi, Kenya, pp: 387-393.

Palm, C. A., Myers, R. J. K. and Nandwa, S. M. (1997), "Combined use of organic and inorganic nutrient sources for fertility maintenance and replenishment", Replenishing soil fertility in Africa, Buresh, R. J. Sanchez P. A. and Calhoun F. (Eds.). SSSA Special Republication 51: 193-217, Soil Science Society of America and American Society of Agronomy, Madison, USA.

Pandey, A., Soccol, C. R., Nigam, P. and Soccol, V. T. (2000), "Biotechnological potential of agroindustrial residues. I: sugarcane bagasse", Bioresource Technology, Vol. 74 No. 1, pp. 69-80.

Rajagopal, V., Paramjit, S. M., Suresh, K. P., Yogeswar, S., Nageshwar, R. D. V. K. and Avinash, N. (2014), "Significance of vinasses waste management in agriculture and environmental quality: Review", African Journal of Agricultural
Research, Vol. 9 No. 38, pp. 28622873.

Sales, A. and Lima, S. A. (2010), "Use of Brazilian sugarcane bagasse ash in concrete as sand replacement", Waste Management, Vol. 30 No. 6, pp. 1114-1122.

Smailing, E. M. A., Nandwa, S. M. and Jansseu, B. H. (1997), "Soil fertility is at stake", Replenishing soil fertility in Africa, Buresh R. J., Sanchez P. A. and Calhoun F. (Eds.), SSSA Special Republication 51:47-61, Soil Science Society of America and American Society of Agronomy, Madison, USA.

Soobadar, A., Rene, N. G. and KeeKwong, K. F. (2012), "Impact of high rates of vinasse on some pertinent soil characteristics and on sugarcane yield in Mauritius", Journal of Sustainable Agriculture, Vol. 36 No. 1, pp. 36-53.

Teow, C. C., Truong, V., McFeeters, R. F., Thompson, R. L., Pecota, K. V. and Yencho, G. C. (2007), "Antioxidant activities, phenolic and b-carotene contents of sweet potato genotypes with varying flesh colours", Food Chemistry, Vol. 103, pp. 829-838.

Tirol-padre, A., Ladha, J. K., Regmi, A. P., Bhandari, A. L. and Lnubushi, K. (2007), "Organic amendment affect soil parameters in two long-term rice-wheat experiments", Soil Science Society of America Journal, Vol. 71 No. 2, pp. 442-452. 
Tumwegamire, S., Kapinga, R., Zhang, D., Crissman, C. and Agili S. (2004), "Opportunities for promoting orange fleshed sweet potato as a mechanism for combating vitamin A deficient in Subsaharan Africa", African Crop Science Journal, 12(3): 241-252.

Vanluawe B, Wendt JW, Diels J (2001), "Combined application of organic matter and fertilizer", Sustaining Soil Fertility in West Africa, Tian G. and Ishida F. (Eds.), SSSA Special Publication Number 58, Soil Science Society of America, Madison, USA.
Webber, C. L., White Jr., P., Douglas, S., and Petrie, C. (2017), "Impact of sugarcane bagasse ash as an amendment on the physical properties, nutrient content and seedling growth of a certified organic greenhouse growing media", Journal of Agricultural Science, Vol. 9 No. 7, pp. 1-11.

Woolfe, J. A. (1992), Sweet potato: An untapped food resource, Cambridge University Press, Cambridge, United Kingdom. 